\title{
Chemokines mediate mesenchymal stem cell migration toward gliomas in vitro
}

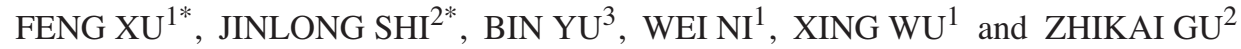 \\ ${ }^{1}$ Department of Neurosurgery, Shanghai Neurosurgical Center, Huashan Hospital, Fudan University, \\ Shanghai 200040; ${ }^{2}$ Department of Neurosurgery, Affiliated Hospital of Nantong Universtiy, Nantong, \\ Jiangsu 226001; ${ }^{3}$ National Laboratory for Oncogenes and Related Genes, WHO Collaborating Center for \\ Research on Cancer, Shanghai Cancer Institute, Shanghai Jiaotong University, Shanghai 200032, P.R. China
}

Received December 21, 2009; Accepted February 26, 2010

DOI: $10.3892 /$ or_00000796

\begin{abstract}
Previous studies have demonstrated the tremendous tropism of mesenchymal stem cells (MSCs) for malignant gliomas, making these cells a potential vehicle for delivery of therapeutic genes to disseminated glioma cells. However, the mechanisms underlying the tropism of MSCs for gliomas remain poorly defined. It has been suggested that malignant gliomas secrete a variety of chemokines, including macrophage chemoattractant protein-1 (MCP-1) and stromal cell-derived factor- $1 \alpha(\mathrm{SDF}-1 \alpha)$. We isolated and cultured MSCs from rat bone marrow and found that these cells express CCR2 and CXCR4, the respective receptors for MCP-1 and SDF-1 $\alpha$. In vitro analysis revealed that MCP- 1 and $\mathrm{SDF}-1 \alpha$ induce the migration of MSCs. Futhermore, neutralization data suggest that MCP-1 and SDF- $1 \alpha$ play a role in the mediation of MSC migration toward gliomas. These results highlight the potential of these cells as a tumor targeting strategy for glioma gene therapy.
\end{abstract}

\section{Introduction}

Malignant gliomas are the most prevalent type of primary brain tumor. Despite extensive surgical excision and adjuvant radio- and chemotherapy, the prognoses of patients with malignant gliomas, such as glioblastoma multiforme (GBM) or anaplastic astrocytoma, remain extremely poor (1-3). The median survival is 1 year or less for patients diagnosed with

Correspondence to: Dr Feng Xu, Department of Neurosurgery, Huashan Hospital, Fudan University, 12 Wulumuqi Zhong Road, Shanghai 200040, P.R. China

E-mail: fengxu.dr@gmail.com

*Contributed equally

Key words: macrophage chemoattractant protein-1, stromal cellderived factor- $1 \alpha$, mesenchymal stem cells, migration, glioma
GBM and $\sim 3$ years for those diagnosed with anaplastic astrocytoma (4). This treatment resistance arises, in part, from tumor infiltration of and invasion into the surrounding brain architecture. Surgical tumor resection is almost always followed by regrowth of tumor cells residing in adjacent regions of normal brain tissue because it is impossible to eliminate successfully all tumor cells using current technologies (5-7). Single tumor cells deeply infiltrate the surrounding tissue, and are thought to be responsible for tumor relapse. New therapies should target these single tumor cells, especially those that have escaped the main tumor mass (8-10).

Neural stem cells (NSCs) possess extensive tropism for experimental gliomas when administered intracranially $(11,12)$. This characteristic of NSCs has been exploited as a tumor targeting strategy for glioma gene therapy (11-20). Unfortunately, the acquisition of sufficient therapeutic NSCs is challenging technically, and their practical application is problematic due to ethical concerns and immunological rejection. Previously, it has been suggested that mesenchymal stem cells (MSCs) may represent an alternative source of therapeutic stem cells $(21,22)$. In experimental brain glioma models, intracranially implanted or intravenously injected MSCs can migrate away from the injection site toward tumor beds (23-27). Additionally, gene modification of MSCs with therapeutic cytokines clearly prolongs the survival of tumorbearing animals $(23,25,28,29)$.

A better understanding of the molecular events that govern MSC homing is necessary for the development of a clinicallyapplicable tumor targeting strategy for glioma gene therapy. Certain chemokines and growth factors, such as vascular endothelial cell growth factor (VEGF), interleukin-8 (IL-8), transforming growth factor- $\beta$ (TGF- $\beta$ ), and neurotrophin-3 (NT-3), released from glioma cells have been reported to mediate the tropism of MSCs for gliomas (30-32). In addition to IL-8, several other chemokines are secreted by glioma cells, including macrophage chemoattractant protein-1 (MCP-1) $(33,34)$ and stromal cell-derived factor-1 $\alpha$ (SDF-1 $\alpha)$ (35-37). Therefore, in this study we analyzed the chemotactic effect of MCP-1 and SDF-1 $\alpha$ on MSCs. In addition, we investigated the role of these chemokines in mediating the migration of MSCs toward gliomas. 
Table I. Gene specific primers for PCR.

\begin{tabular}{lll}
\hline Gene & GenBank accession no. & \multicolumn{1}{c}{ Oligonucleotide $\left(5^{\prime} \rightarrow 3^{\prime}\right)$} \\
\hline MCP-1 & NM_031530.1 & $\begin{array}{l}\text { Forward: TGTCACGCTTCTGGGCCTGTTG } \\
\text { Reverse: CAGAAGTGCTTGAGGTGGTTGTGGAA }\end{array}$ \\
SDF-1 $\alpha$ & AF189724.1 & Forward: CTGTGCTGGCCCTGGTGCTG \\
& NM_021866.1 & Feverse: CGGGTCAATGCACACTTGTCTGTTGT \\
CCR2 & Forward: TGATCCTGCCCCTACTTGTCATGG \\
& NM_022205.3 & Feverse: GAGCTCACTCGGTCTGCTGTCTCC \\
CXCR4 & Forward: AGCCAGGGGGACGGCAGGTA \\
& Reverse: TGCTGCGCGGAGCTCTTGAA \\
\hline
\end{tabular}

\section{Materials and methods}

MSC preparation. According to institutional guidelines and an approved protocol, bone marrow aspirates from Fischer 344 rats (9 weeks old, male) were plated and cultured in Dulbecco's minimal essential medium (DMEM; Gibco/BRL, Rockville, MD, USA) supplemented with $10 \%$ fetal bovine serum (FBS; Gibco/BRL), $100 \mathrm{U} / \mathrm{ml}$ penicillin, $100 \mu \mathrm{g} / \mathrm{ml}$ streptomycin, and $2 \mathrm{mM}$ L-glutamine (Gibco/BRL) as described previously (25). Rat MSCs (rMSCs) were adherent, elongated, and spindle-shaped in the primary culture after $24 \mathrm{~h}$ of plating. After $24 \mathrm{~h}$, non-adherent cells were removed by changing the medium; thereafter, the medium was changed twice a week. rMSCs reached $80 \%$ confluence after 12-14 days. Cells were harvested by trypsinization and passaged for expansion purposes. rMSCs were used at passage 2 in all experiments (flow cytometry analysis, RT-PCR, and migration assays).

Glioma cell conditioned medium. Rat glioma C6 cells (American Type Culture Collection, Rockville, MD) were cultured in 45\% DMEM, 45\% Ham's F-12 medium, and 10\% FBS with an antibiotic supplement in $75 \mathrm{~cm}^{2}$ culture flasks. Confluent cultures were washed with medium without the addition of FBS and incubated with serum-free medium for 4 days. After conditioning, the medium was aspirated from the cells, centrifuged at $1,000 \mathrm{xg}$ for $5 \mathrm{~min}$, and filtered through $0.22 \mu \mathrm{m}$-diameter pore Millipore filters. Aliquots of the conditioned medium (CM) were stored frozen until required.

Flow cytometry analysis. rMSCs were treated with $0.25 \%$ trypsin-EDTA, harvested, and washed twice with DMEM. Before staining, cells were allowed $2 \mathrm{~h}$ in suspension to recover expression of surface markers. Cell staining was performed using primary antibodies followed by fluorescein isothiocyanate (FITC)-conjugated rabbit anti-goat IgG or FITC-conjugated goat anti-mouse secondary antibodies (Sigma). The following primary antibodies were used in this study: goat polyclonal CCR2 and CXCR4 (Santa Cruz Biotechnology, CA, USA), mouse anti-rat CD11b (Serotec, Oxford, UK), mouse anti-rat CD45, CD44, and CD73 and isotype-specific mouse IgG (Pharmingen, San Diego, CA).
Stained cells were analyzed using a FACScan flow cytometer (Becton-Dickinson, Mountain View, CA).

$R T$-PCR. Total RNA was extracted from C6 glioma cells and rMSCs using TRIzol (Invitrogen, Carlsbad, CA) according to the manufacturer's instructions. The RNAs were reverse transcribed using the SuperScript III First-Strand synthesis system (Invitrogen) with oligo(dT) as primers. PCR reactions were performed in a DNA Thermal Cycler 480 (PerkinElmer Life Sciences, Boston, MA) and the amplifications were carried out in a volume of $12.5 \mu 1$ containing $1 \mu \mathrm{g}$ cDNA, $10 \mathrm{mM}$ Tris- $\mathrm{HCl}, 50 \mathrm{mM} \mathrm{KCl}, 0.2 \mathrm{mM}$ of each dNTP, $1.5 \mathrm{mM}$ $\mathrm{MgCl}_{2}, 10 \mathrm{pmol}$ of each primer, and $0.1 \mathrm{U}$ Taq polymerase, for $5 \mathrm{~min}$ at $94^{\circ} \mathrm{C}$ for initial denaturing, followed by 32 cycles of $94^{\circ} \mathrm{C}$ for $30 \mathrm{sec}, 60^{\circ} \mathrm{C}$ for $30 \mathrm{sec}$ and $72^{\circ} \mathrm{C}$ for $30 \mathrm{sec}$, and a final incubation at $72^{\circ} \mathrm{C}$ for $7 \mathrm{~min}$. PCR products were sized fractioned by electrophoreis on $2 \%$ agarose gels and visualized with ethidium bromide. The specific primers used are shown in Table I.

Migration assays. rMSC migration was performed in Transwell dishes (Costar) $6.5-\mathrm{mm}$ in diameter, with $8-\mu \mathrm{m}$ pore filters. $\mathrm{rMSCs}\left(4 \times 10^{5} / \mathrm{ml}\right)$ in $200 \mu \mathrm{l}$ of serum-free DMEM were added to the upper chamber and $600 \mu \mathrm{l}$ of tested samples containing chemokines, glioma cell CM, or CM supplemented with specific neutralized antibodies were placed in the lower chambers. Recombinant rat MCP-1 (rrMCP-1; Perprotech, NJ, USA) and recombinant human SDF- $1 \alpha$ (rhSDF- $1 \alpha$; R\&D Systems, Wiesbaden, Germany) were diluted in serum-free DMEM to different concentrations ranging from $4 \mathrm{ng} / \mathrm{ml}$ to $500 \mathrm{ng} / \mathrm{ml}$. Medium incubated in the absence of cells served as a negative control. After overnight incubation in $5 \% \mathrm{CO}_{2}$ at $37^{\circ} \mathrm{C}$, cells remaining on the upper face of the filters were removed with a cotton wool swab. Chambers were fixed for $20 \mathrm{~min}$ at room temperature with $4 \%$ formaldehyde in PBS, stained in $0.5 \%$ cresyl violet for $20 \mathrm{~min}$, and rinsed in water. Cells that had migrated through the pores and adhered to the lower surface of the membrane were analyzed under highpower (x400) light microscopy and counted in five random high-power fields. For neutralization studies, glioma cell $\mathrm{CM}$ was incubated with rabbit anti-rat MCP-1 antibody (Cedarlane Laboratories Ltd., Ontario, Canada) or rMSCs 

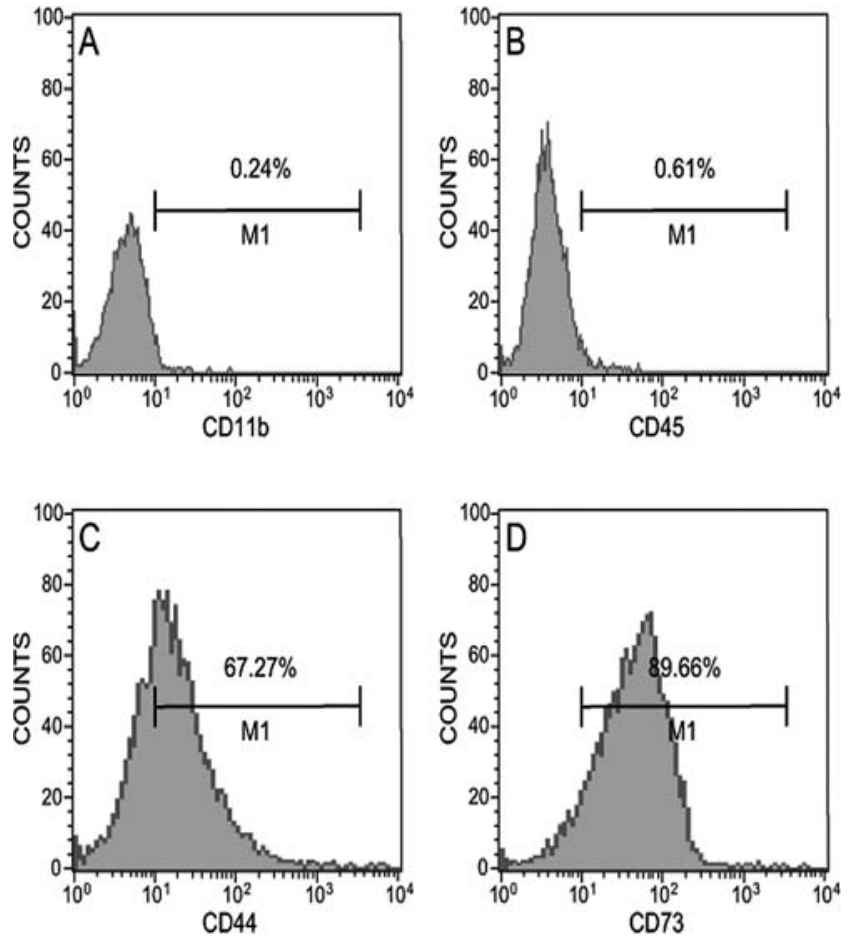

Figure 1. Graphs summarize FACS analysis of rMSC expression of cell surface markers. (A) rMSCs $(0.24 \%)$ reacted with the anti-CD11b antibody; (B) $0.61 \%$ of rMSCs reacted with the anti-CD45 antibody; (C) $67.27 \%$ of rMSCs reacted with the anti-CD44 antibody; (D) $89.66 \%$ of rMSCs reacted with the anti-CD73 antibody.

were incubated with anti-CXCR4 polyclonal antibody (MBL, Nagoya, Japan).

Statistical methods. Each experiment was performed a minimum of 3 times. For migration assays, data are expressed as the mean number of cells per high-power field (cells/HPF) \pm standard error (SE). Statistical analysis was performed using Student's t-tests. Statistical significance was set at $\mathrm{p}<0.05$.

\section{Results}

Before performing specific studies, we verified that the cultured cells were negative for CD11b and CD45 surface markers and positive for CD44 and CD73 surface markers (Fig. 1). We also confirmed that the cultured cells demonstrated multipotentiality by giving rise to osteoblasts and adipocytes when exposed to adequate differentiating conditions (data not shown).

C6 glioma cells produce MCP-1 and SDF-1 . It has been shown that MCP-1 and SDF- $1 \alpha$ are produced by glioma cells in vitro and in vivo (33-37). We hypothesized that these chemokines released by glioma cells may be potential mediators of MSC migration. To test this hypothesis, we examined their expression in C6 glioma cells. Using RT-PCR, we observed that $\mathrm{C} 6$ glioma cells express the transcripts for MCP-1 and SDF-1 $\alpha$ (Fig. 2A).

MSCs express the chemokine receptors CCR2 and CXCR4. To study the role of chemokine receptors in cell migration
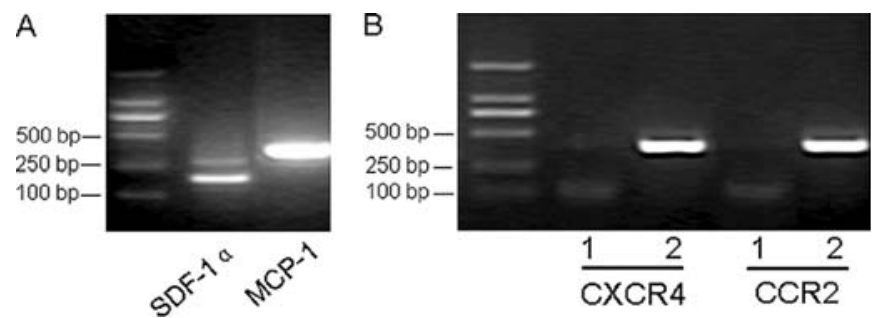

Figure 2. RT-PCR analysis of MCP-1, SDF-1 $\alpha$, CCR2, and CXCR4 mRNA levels. (A) MCP-1 and SDF-1 $\alpha$ mRNA were expressed in rat C6 glioma cells. (B) CCR2 and CXCR4 mRNA were expressed in rMSCs, but not in fibroblasts (non-migratory cells as control). Lane 1: fibroblasts; lane 2: rMSCs.

toward gliomas, we then examined the expression of CCR2 and CXCR4 (the receptors for MCP-1 and SDF-1 $\alpha$, respectively) in rMSCs. Considering of non-migratory properties of fibroblasts toward glioma cells in vitro (27), we used fibroblasts as control cells in RT-PCR assays. It showed that CCR2 and CXCR4 mRNA were expressed in rMSCs, but not in fibroblasts (Fig. 2B).

To confirm RT-PCR data, we further examined protein expression of CCR2 and CXCR4 in rMSCs by flurescenceactivated cell sorter (FACS) analysis. It demonstrated that a small percentage of rMSCs $(14.85 \%)$ react with the antiCXCR4 antibody and a high percentage of rMSCs (32.15\%) react with the anti-CCR2 antibody (Fig. 3).

MSCs migrate in response to MCP-1 and SDF-1a. In light of the observation that rMSCs express CCR2 and CXCR4, an in vitro chemotaxis assay was performed using rrMCP-1 and rhSDF-1 $\alpha$. We found a significant increase in rMSCs migration with rrMCP-1 at concentrations of 4 and $20 \mathrm{ng} / \mathrm{ml}(\mathrm{p}<0.01)$ (Fig. 4A). Interestingly, higher concentrations of rrMCP-1 (100 and $500 \mathrm{ng} / \mathrm{ml}$ ) did not result in significant rMSCs migration. However, rhSDF-1 $\alpha$ induced migration of rMSCs in a dose-dependent manner; the maximum migration of rMSCs was observed at $100 \mathrm{ng} / \mathrm{ml}$ of rhSDF-1 $\alpha$ (Fig. 4B). Pretreatment of rMSCs with a blocking anti-MCP-1 antibody $(10 \mu \mathrm{g} / \mathrm{ml})$ or with anti-CXCR4 antibody $(10 \mu \mathrm{g} / \mathrm{ml})$ abrogated cell migration in response to $\operatorname{rrMCP}-1$ and $\operatorname{rhSDF}-1 \alpha$, respectively, confirming the specificity of the migration (data not shown).

MCP-1 and SDF-1a play a role in mediating MSC migration toward gliomas. To determine whether glioma-secreted chemokines contribute to MSCs chemotaxis, we incubated C6 glioma cell CM with anti-MCP-1 antibody $(10 \mu \mathrm{g} / \mathrm{ml})$, or/ and incubated rMSCs with anti-CXCR4 antibody $(10 \mu \mathrm{g} / \mathrm{ml})$. Whereas C6 glioma cell CM resulted in a significant increase in rMSC migration, addition of the anti-MCP-1 neutralizing antibody significantly attenuated the migration of rMSCs (Fig. 5). Similarly, following incubation with an anti-CXCR4 blocking antibody, a significant decrease was found in rMSC migration toward C6 glioma cell CM. Importantly, this inhibition was even more pronounced when both antibodies were added. These results suggest that MCP-1 and SDF- $1 \alpha$ are important for the mediation of MSC migration toward gliomas. 

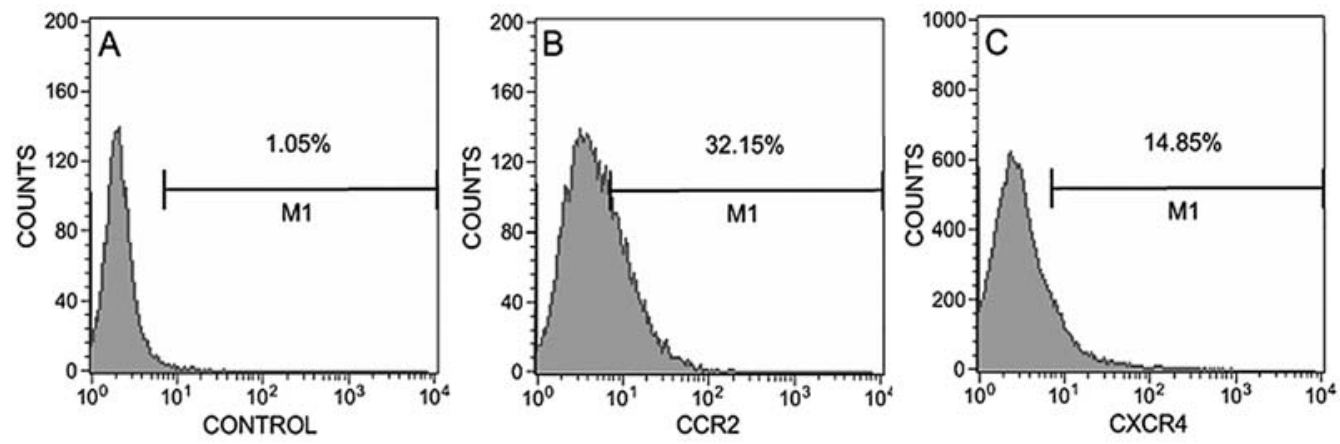

Figure 3. Graphs summarize FACS analysis of rMSC expression of CCR2 and CXCR4. (A) rMSCs (1.05\%) reacted with the isotype-specific Ig and FITClabeled secondary antibody; (B) 32.15\% of rMSCs reacted with the anti-CCR2 antibody; (C) 14.85\% of rMSCs reacted with the anti-CXCR4 antibody.
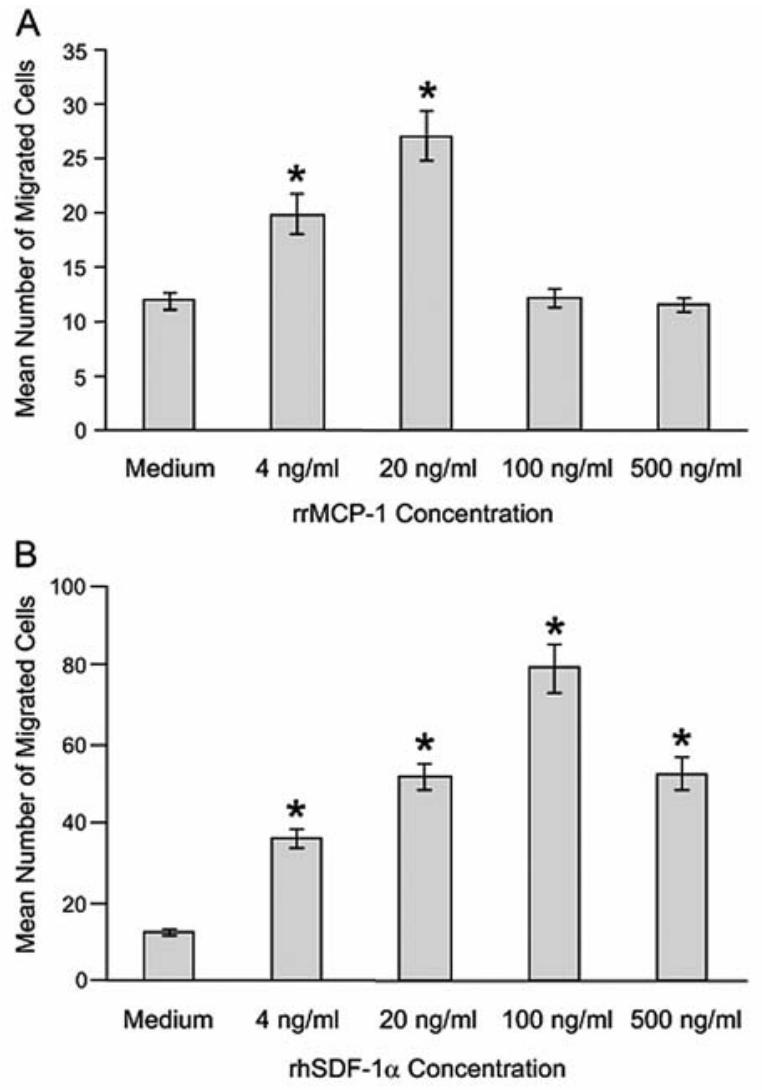

Figure 4. Graphs summarize chemokine-mediated migration of MSCs in vitro. (A) Effect of rrMCP-1 on MSC migration. A significant increase in the number of migrated MSCs was found at rrMCP-1 concentrations of 4 and $20 \mathrm{ng} / \mathrm{ml}\left({ }^{*} \mathrm{p}<0.01\right)$, when compared with control. (B) Effect of rhSDF-1 $\alpha$ on MSC migration. The number of migrated MSCs increased dose-dependently at rhSDF- $1 \alpha$ concentrations of $4-500 \mathrm{ng} / \mathrm{ml}($ ( $\mathrm{p}<0.01)$, when compared with control. The maximum effect of rhSDF- $1 \alpha$ was observed at a concentration of $100 \mathrm{ng} / \mathrm{ml}$.

\section{Discussion}

The robust tropism of stem cells for intracranial gliomas makes them highly attractive as vehicles for the delivery of a wide variety of therapeutic gene products directly to tumor cells. Understanding the mechanisms underlying the migration of stem cells toward malignant gliomas is crucial to the success of clinical implementation of a tumor-targeting strategy involving MSCs. Herein, we demonstrate that specific chemokines such as MCP-1 and SDF-1 $\alpha$ mediate the migration of MSCs toward gliomas in vitro.

MCP-1, a member of the CC chemokine family with chemoattractant activity for major inflammatory cells, is produced by malignant gliomas in vitro as well as in vivo $(33,34)$. MCP-1 expression is associated with a higher astrocytoma tumor grade $(34,38)$. Moreover, MCP-1 can play a role in macrophage recruitment into gliomas in vivo $(38,39)$. Previously it has been suggested that MCP-1 might be responsible for MSC migration toward ischemic cerebral tissue (40). In our study, we demonstrate MCP-1 receptor CCR2 expression in rMSCs, and the chemotaxis of rMSCs in response to MCP-1. Furthermore, addition of the anti-MCP-1 neutralizing antibody significantly attenuated the migration of MSCs toward gliomas. Therefore, MCP-1 might play an important role in MSC migration toward gliomas. This is consistent with a recent study demonstrating that MCP-1 secreted by primary breast tumors stimulates migration of MSCs (41). Interestingly, MCP-1 was found to be upregulated in rat MSCs exposed to tumor environment (42). However, there are conflicting reports showing that human MSCs do not migrate in response to MCP-1 (43). These contradictory findings may be explained by varying culture homogeneity.

The CXC chemokine SDF-1 $\alpha$, which binds to its receptor CXCR4, plays an important and unique role in regulation of stem/progenitor cell trafficking (44). Previous studies have demonstrated that high-grade gliomas secrete significant levels of SDF-1 $\alpha$, and that the expression of this protein and the CXCR4 receptor correlates with the histological grade and invasive capacity of these tumors, as well as tumor cell survival (35-37). SDF-1 $\alpha$ expression by tumor-derived endothelium serves to attract the migration of NSCs $(45,46)$. Ehtesam et al (47) demonstrated that SDF-1 $\alpha /$ CXCR4 interactions play a functional role in gliomatropic migration of NSCs. Tabatabai et al (48) also documented that SDF$1 \alpha /$ CXCR 4 interactions appear to be essential for the gliomatropism of circulating adult haematopoietic progenitor cells. Similarly, we found that SDF-1 $\alpha$ induces the migration of CXCR4-expressing MSCs in vitro. Moreover, neutralization data suggest that SDF- $1 \alpha$ might be involved in the migration of MSCs toward gliomas.

In conclusion, we demonstrated that MSCs express the chemokine receptors CCR2 and CXCR4, and consistent with 

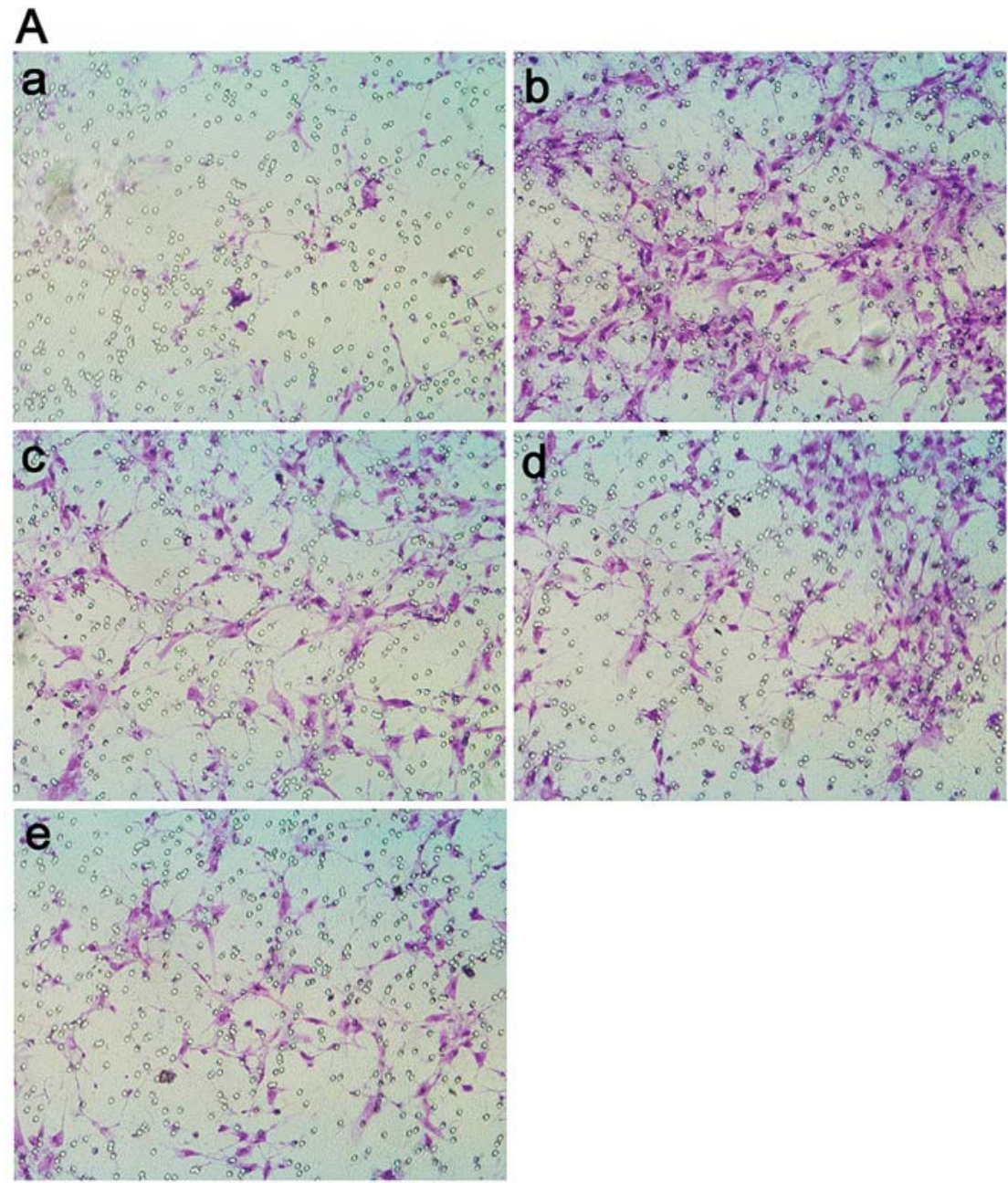

\section{B}

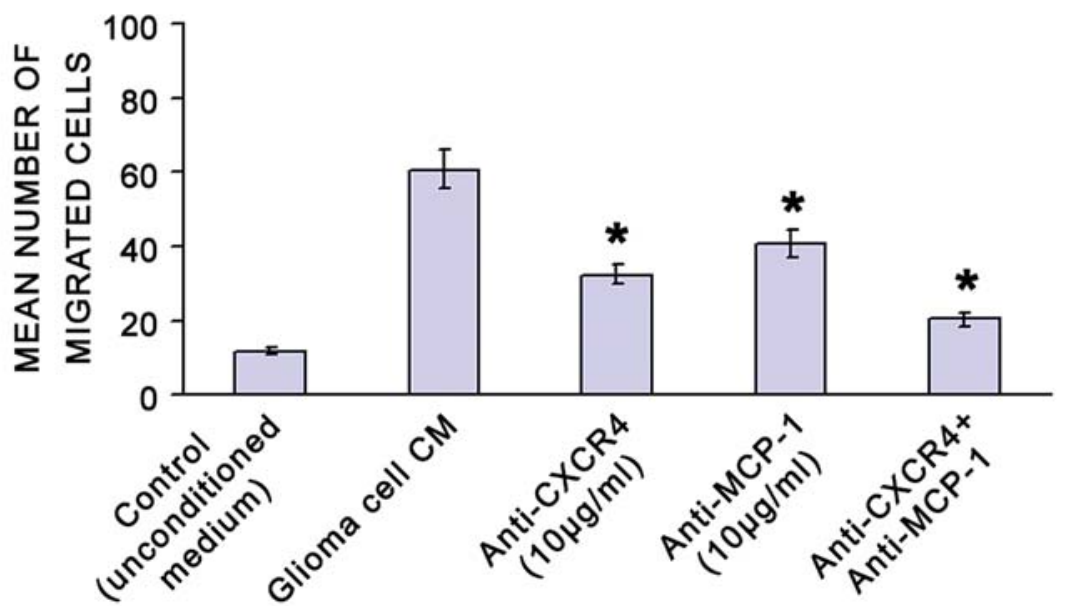

Figure 5. Panel A, photographs of cresyl violet-stained membranes. (a) MSC migration toward normal unconditioned medium. (b) MSC migration toward glioma cell CM. (c) MSC migration toward glioma cell CM after addition of anti-CXCR4 blocking antibody. (d) MSCs migration toward glioma cell CM after addition of anti-MCP-1 neutralizing antibody. (e) MSCs migration toward glioma cell CM after combination of antibodies. Panel B, graph summarizes migration of MSCs toward gliomas after neutralization. Results indicated that C6 glioma cell CM significantly induced the migration of MSCs compared with normal unconditioned medium. Glioma cell CM was incubated with $10 \mu \mathrm{g} / \mathrm{ml}$ anti-MCP-1, rMSCs were preincubated with $10 \mu \mathrm{g} / \mathrm{ml}$ anti-CXCR4, or both conditions were observed. $\left({ }^{*} \mathrm{p}<0.01\right)$.

this they migrate in response to the chemokines MCP-1 and SDF-1 $1 \alpha$. Moreover, we have shown that MCP- 1 and SDF-1 $\alpha$ mediate the migration of MSCs toward gliomas. However, the in vitro migration assay employed in this study may not directly mimic the in vivo conditions necessary for migration of MSCs from the vasculature to the tumor. Further elucidation 
of the mechanisms underlying the migration of MSCs toward gliomas may provide insights into methods for increasing the effectiveness of cell engraftment.

\section{Acknowledgements}

The authors thank Dr Hongshan Chen and Dr Xiongfei Xu for their skillful technical assistance.

\section{References}

1. Legler JM, Ries LA, Smith MA, Warren JL, Heineman EF, Kaplan RS and Linet MS: Cancer surveillance series [corrected]: brain and other central nervous system cancers: recent trends in incidence and mortality. J Natl Cancer Inst 91: 1382-1390, 1999.

2. Surawicz TS, Davis F, Freels S, Laws ER Jr and Menck HR: Brain tumor survival: results from the National Cancer Data Base. J Neurooncol 40: 151-160, 1998

3. Surawicz TS, McCarthy BJ, Kupelian V, Jukich PJ, Bruner JM and Davis FG: Descriptive epidemiology of primary brain and CNS tumors: results from the Central Brain Tumor Registry of the United States, 1999-1994. Neuro Oncol 1: 14-25, 1999.

4. DeAngelis LM: Brain tumors. N Engl J Med 344: 114-123, 2001.

5. Grossman SA and Batara JF: Current management of glioblastoma multiforme. Semin Oncol 31: 635-644, 2004

6. Keles GE and Berger MS: Advances in neurosurgical technique in the current management of brain tumors. Semin Oncol 31 $659-665,2004$.

7. Lefranc F, Brotchi $\mathbf{J}$ and Kiss R: Possible future issues in the treatment of glioblastomas: special emphasis on cell migration and the resistance of migrating glioblastoma cells to apoptosis. J Clin Oncol 23: 2411-2422, 2005.

8. Dunn IF and Black PM: The neurosurgeon as local oncologist: cellular and molecular neurosurgery in malignant glioma therapy. Neurosurgery 52: 1411-1422, 2003.

9. Rich JN and Bigner DD: Development of novel targeted therapies in the treatment of malignant glioma. Nat Rev Drug Discov 3: 430-446, 2004

10. Yasargil MG, Kadri PA and Yasargil DC: Microsurgery for malignant gliomas. J Neurooncol 69: 67-81, 2004.

11. Aboody KS, Brown A, Rainov NG, Bower KA, Liu S, Yang W, Small JE, Herrlinger U, Ourednik V, Black PM, Breakefield XO and Snyder EY: Neural stem cells display extensive tropism for pathology in adult brain: evidence from intracranial gliomas. Proc Natl Acad Sci USA 97: 12846-12851, 2000.

12. Benedetti S, Pirola B, Pollo B, Magrassi L, Bruzzone MG, Rigamonti D, Galli R, Selleri S, DiMeco F, DeFraja C, Vescovi A, Cattaneo E and Finocchiaro G: Gene therapy of experimental brain tumors using neural progenitor cells. Nat Med 6: 447-450, 2000 .

13. Ehtesham M, Kabos P, Gutierrez MA, Chung NH, Griffith TS, Black KL and Yu JS: Induction of glioblastoma apoptosis using neural stem cell-mediated delivery of tumor necrosis factorrelated apoptosis-inducing ligand. Cancer Res 62: 7170-7174, 2002.

14. Ehtesham M, Kabos P, Kabosova A, Neuman T, Black KL and Yu JS: The use of interleukin 12-secreting neural stem cells for the treatment of intracranial glioma. Cancer Res 62: 5657-5663, 2002.

15. Brown AB, Yang W, Schmidt NO, Carroll R, Leishear KK, Rainov NG, Black PM, Breakefield XO and Aboody KS. Intravascular delivery of neural stem cell lines to target intracranial and extracranial tumors of neural and non-neural origin. Hum Gene Ther 14: 1777-1785, 2003

16. Shah K, Tang Y, Breakefield X and Weissleder R: Real-time imaging of TRAIL-induced apoptosis of glioma tumors in vivo. Oncogene 22: 6865-6872, 2003.

17. Yang SY, Liu H and Zhang JN: Gene therapy of rat malignant gliomas using neural stem cells expressing IL-12. DNA Cell Biol 23: 381-389, 2004

18. Kim S-K, Cargioli TG, Machluf M, Yang W, Sun Y, AlHashem R, Kim SU, Black PM and Carroll RS: PEX-producing human neural stem cells inhibit tumor growth in a mouse glioma model. Clin Cancer Res 11: 5965-5970, 2005.
19. Uhl M, Weiler M, Wick W, Jacobs AH, Weller M and Herrlinger U: Migratory neural stem cells for improved thymidine kinase-based gene therapy of malignant gliomas. Biochem Biophys Res Commun 328: 125-129, 2005.

20. Lorico A, Mercapide J, Soloduschko V, Alexeyev M, Fodstad O and Rappa G: Primary neural stem/progenitor cells expressing endostatin or cytochrome P450 for gene therapy of glioblastoma. Cancer Gene Ther 15: 605-615, 2008.

21. Hamada H, Kobune M, Nakamura K, Kawano Y, Kato K, Honmou O, Houkin K, Matsunaga T and Niitsu Y: Mesenchymal stem cells (MSC) as therapeutic cytoreagents for gene therapy. Cancer Sci 96: 149-156, 2005.

22. Phinney DG and Isakova I: Plasticity and therapeutic potential of mesenchymal stem cells in the nervous system. Curr Pharm Des 11: 1255-1265, 2005.

23. Studeny M, Marini FC, Champlin RE, Zompetta C, Fidler IJ and Andreeff M: Bone marrow-derived mesenchymal stem cells as vehicles for interferon-\{beta\} delivery into tumors. Cancer Res 62: 3603-3608, 2005.

24. Lee J, Elkahloun AG, Messina SA, Ferrari N, Xi D, Smith CL, Cooper R Jr, Albert PS and Fine HA: Cellular and genetic characterization of human adult bone marrow-derived neural stem-like cells: a potential antiglioma cellular vector. Cancer Res 63: 8877-8889, 2003.

25. Nakamura K, Ito Y, Kawano Y, Kurozumi K, Kobune M, Tsuda H, Bizen A, Honmou O, Niitsu Y and Hamada H: Antitumor effect of genetically engineered mesenchymal stem cells in a rat glioma model. Gene Ther 11: 1155-1164, 2004.

26. Nakamizo A, Marini F, Amano T, Khan A, Studeny M, Gumin J, Chen J, Hentschel S, Vecil G, Dembinski J, Andreeff M and Lang FF: Human bone marrow-derived mesenchymal stem cells in the treatment of gliomas. Cancer Res 65: 3307-3318, 2005.

27. Wu X, Hu J, Zhou L, Mao Y, Yang B, Gao L, Xie R, Xu F, Zhang D, Liu J and Zhu J: In vivo tracking of super paramagnetic iron oxide nanoparticle-labeled mesenchymal stem cell tropism to malignant gliomas using magnetic resonance imaging. J Neurosurg 108: 320-329, 2008.

28. Kim SM, Lim JY, Park SI, Jeong CH, Oh JH, Jeong M, Oh W, Park SH, Sung YC and Jeun SS: Gene therapy using TRAILsecreting human umbilical cord blood-derived mesenchymal stem cells against intracranial glioma. Cancer Res 68: 9614-9623, 2008.

29. Hong X, Miller C, Savant-Bhonsale S and Kalkanis SN: Antitumor treatment using interleukin-12-secreting marrow stromal cells in an invasive glioma model. Neurosurgery 64: 1139-1146, 2009.

30. Schichor C, Birnbaum T, Etminan N, Schnell O, Grau S, Miebach S, Aboody K, Padovan C, Straube A, Tonn JC and Goldbrunner R: Vascular endothelial growth factor A contributes to glioma-induced migration of human marrrow stromal cells (hMSC). Exp Neurol 199: 301-310. 2006.

31. Birnbaum T, Roider J, Schankin CJ, Padovan CS, Schichor C, Goldbrunner R and Straube A: Malignant gliomas actively recruit bone marrow stromal cells by secreting angiogenic cytokines. J Neurooncol 83: 241-247, 2007.

32. Kim DS, Kim JH, Lee JK, Choi SJ, Kim JS, Jeun SS, Oh W, Yang YS and Chang JW: Overexpression of CXC chemokine receptors is required for the superior glioma-tracking property of umbilical cord blood-derived mesenchymal stem cells. Stem Cells Dev 18: 511-519, 2009.

33. Takeshima H, Kuratsu JI, Takeya M, Yoshimura T and Ushio $Y$ : Expression and localization of messenger RNA and protein for monocyte chemoattractant protein-1 in human malignant glioma. J Neurosurg 80: 1056-1062, 1994.

34. Desbaillets I, Tada M, Tribolet N, Diserens AC, Hamou MF and Van Meir EG: Human astrocytomas and glioblastomas express monocyte chemoattractant protein (MCP-1) in vivo and in vitro. Int J Cancer 58: 240-247, 1994.

35. Rempel SA, Dudas S, Ge S and Gutiérrez JA: Identification and localization of the cytokine SDF1 and its receptor, CXC chemokine receptor 4 , to regions of necrosis and angiogenesis in human glioblastoma. Clin Cancer Res 6: 102-111, 2000.

36. Zhou Y, Larsen PH, Hao C and Yong VW: CXCR4 is a major chemokine receptor on glioma cells and mediates their survival. J Biol Chem 277: 49481-49487, 2002.

37. Barbero S, Bonavia R, Bajetto A, Porcile C, Pirani P, Ravetti JL, Zona GL, Spaziante R, Florio T and Schettini G: Stromal cellderived factor 1 \{alpha\} stimulates human glioblastoma cell growth through the activation of both extracellular signalregulated kinases 1/2 and Akt. Cancer Res 63: 1969-1974, 2003. 
38. Leung SY, Wong MP, Chung LP, Chan AS and Yuen ST: Monocyte chemoattractant protein-1 expression and macrophage infiltration in gliomas. Acta Neuropathol 93: 518-527, 1997.

39. Kielian T, Van Rooijen N and Hickey WF: MCP-1 expression in CNS-1 astrocytoma cells: implications for macrophage infiltration into tumors in vivo. J Neurooncol 56: 1-12, 2002.

40. Wang L, Li Y, Chen J, Gautam SC, Zhang Z, Lu M and Chopp M: Ischemic cerebral tissue and MCP-1 enhance rat bone marrow stromal cell migration in interface culture. Exp Hematol 30: 831-836, 2002.

41. Dwyer RM, Potter-Beirne SM, Harrington KA, Lowery AJ, Hennessy E, Murphy JM, Barry FP, O'Brien T and Kerin MJ: Monocyte chemotactic protein-1 secreted by primary breast tumors stimulates migration of mesenchymal stem cell. Clin Cancer Res 13: 5020-5027, 2007.

42. Menon LG, Picinich S, Koneru R, Gao H, Lin SY, Koneru M, Mayer-Kuckuk P, Gold J and Banerjee D: Differential gene expression associated with migration of mesenchymal stem cells to conditioned medium from tumor cells or bone marrow cells. Stem Cells 25: 520-528, 2007.

43. Ringe J, Strassburg S, Neumann K, Endres M, Notter M, Burmester GR, Kaps C and Sittinger M: Towards in situ tissue repair: Human mesenchymal stem cells express chemokine receptors CXCR1, CXCR2 and CCR2, and migrate upon stimulation with CXCL8 but not CCL2. J Cell Biochem 101: 135-146, 2007.
44. Peled A, Petit I, Kollet O, Ponomaryov R, Zipori D and Lapidot T: Dependence of human stem cell engraftment and repopulation of NOD/SCID mice on CXCR4. Science 283: 845-848, 1999.

45. Allport JR, Shinde Patil VR and Weissleder R: Murine neuronal progenitor cells are preferentially recruited to tumor vasculature via alpha4-integrin and SDF-1alpha-dependent mechanisms. Cancer Biol Ther 3: 838-844, 2004.

46. Fears CY, Sontheimer HW, Bullard DC and Gladson CL: Could labeled neuronal progenitor cells be used to target glioma tumor endothelium? Cancer Biol Ther 3: 845-846, 2004.

47. Ehtesham M, Yuan X, Kabos P, Chung NH, Liu G, Akasaki Y, Black KL and Yu JS: Glioma tropic neural stem cells consist of astrocytic precursors and their migratory capacity is mediated by CXCR4. Neoplasia 6: 287-293, 2004.

48. Tabatabai G, Bähr O, Möhle R, Eyüpoglu IY, Boehmler AM, Wischhusen J, Rieger J, Blümcke I, Weller M and Wick W: Lessons from the bone marrow: how malignant glioma cells attract adult haematopoietic progenitor cells. Brain 128: 2200-2211, 2005. 